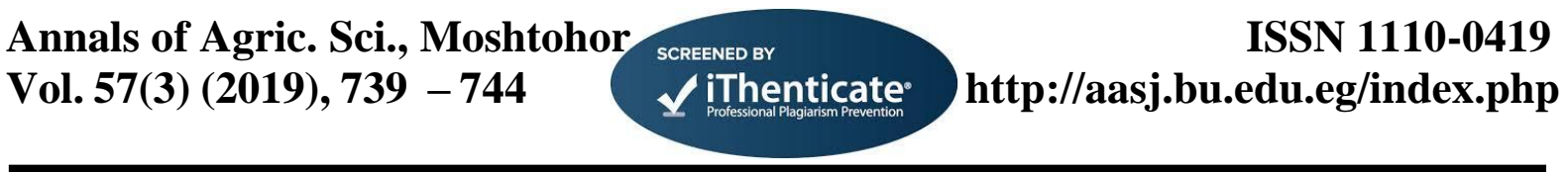

\title{
Toxicity of Different Nano Oils Formulation against Adults of Rice Weevil, Sitophilus Oryzae under Laboratory Conditions.
}

\author{
Amira M. EL-Shewy \\ Plant Protection Department, Faculty of Agriculture, Benha University, Egypt.
}

\begin{abstract}
Silica particles, cinnamon and mentha oils were prepared in the form of nano product. Sitophilus oryzae adults were treated with this product. Results indicated that nano silica particles have a greater toxic effect followed by nano cinnamon oil while, nano mentha oil recorded the least one. Hence, the lethat concentration $\left(\mathrm{LC}_{50}\right)$ and lethal time $\left(\mathrm{LT}_{50}\right)$ of nano silica were $0.125 \%$ and 1.68 days on the adults of $S$. oryzae followed by $0.163 \%$ and 2.09 days for nano cinnamon oil. Finally, nano mentha oil which recorded $0.321 \%$ and 2.32 days, respectively. The mortality rate reached $100 \%$ at the second week of treatment for nano silica followed by 91.11 and $90.6 \%$ for nano cinnamon and mentha oils, respectively. Reduction in progeny ranged from 64.60-100, 64.6-96.2 and 61.095.5\% for nano silica, nano cinnamon and mentha oils, respectively. Results showed relatively no significant differences in germination of wheat grains treated with both of nano cinnamon and mentha oils, but significant differences were found in germination of wheat grains treated with nano silica. These forms need more studies to know their safety and effects on environment when they apply for controlling the insects.
\end{abstract}

Keywords: nano- particles, Sitophilus oryzae, $\mathrm{LC}_{50}, \mathrm{LT}_{50}$, Germination, wheat grain

\section{Introduction}

Over the years, insects damage stored grains and cereal products have been of great concern to control them relies heavily on the continued applications of synthetic insecticides and fumigants (Shaaya et al., 1991; Lee etal., 2003). The rice weevil, sitophilus oryzae has been reported as one of the severe pests of grains and their products (Baloch, 1992), causing loss in grains weight and leading to quality deterioration and fungal growth in harvested cereals (Park $\boldsymbol{e t}$ al., 2003). Loss in wheat due to stored insects is estimated as equivalent to half million tons of which $12 \%$ is caused by the rice weevil alone. The control of rice weevil and other stored pests by use the chemical insecticides have many serious draw backs in the environment and also, caused high mammalian toxicity. In this study, we made an effort to search for safer and less expensive alternative control method such as plant oils. Oils are safe to mammals, easily obtained and play important role in the protection of stored products. Nanotechnology considered one of the main technologies of the $21^{\text {st }}$ century. Nanotechnology reduced the size of the smallest structures to the nanoscales e.g. Photonics applications in nano electronics and nano engineering, (White sides and Gryzbowski, 2002). Nano from products is new technologies which help to produce new pesticides and insect repellants (Owolade and ogunleti, 2008). A few researches have been carried out to investigate the toxic effects of nanoparticles on insects especially for stored product insect pests.

This study was designed to investigate the efficiency of nano emulsions of silica and mentha and cinnamon oils as protecting agents of wheat grains against infestation with rice weevil, Sitophilus oryzae adults.

\section{Materials and Methods}

\section{1- Tested insect: -}

The rice weevil, Sitophilus oryzae (L.) (curculionidae, Coleoptera) was used. The experiment was performed in the stored product pest's laboratory at the Plant Protection Department, Faculty of Agriculture, Moshtohor, Benha University.

\section{2- Insect cultures}

The insect was reared in glass jars (approx. 500 $\mathrm{ml}$ ) containing about $200 \mathrm{~g}$ of sterilized wheat grains. The glass jars were covered with muslin. Insect cultures were kept under controlled conditions of $28 \pm$ $1{ }^{\circ} \mathrm{C}$ and $65 \pm 5 \%$ R.H at the rearing room of the laboratory. Wheat grains were treated by freezing at $18^{\circ} \mathrm{C}$ for weeks before application to eliminate any possible infestation by any insect species. The moisture content of the grains was around 14\% .300 adults of insect (1-2 weeks old) were introduced into the jars to lay eggs under controlled conditions. Three days later, all insects were separated from the food and the jars with grains were kept in rearing room. This procedure was repeated several times in order to obtain large numbers of the adults needed for the experiments.

\section{3- Preparation of the tested insect for various treatments: -}

Batches of 30 S.oryzae adults were used in all experiments of nano oils. Three replicated were conducted in each treatment.

4- Compound and nano essential oils used:

4.1. Silica nano particles (SiNPs):

The SiNPs size was $100 \mathrm{~nm}$ with a purity of $99.99 \%$.

4.2. Nano essential oils used.

- Mentha piperita (Lamiaceae) 
- Cinnamomum verum (Lauraceae)

5- Nano plant oils preparation:

\subsection{Mentha oil nano-particles preparation:}

The oil in water nano-emulsion was formulated using mentha oil, non-ionic surfactant (tween 80) and deionized water. The concentration of mentha $(4 \%$, $\mathrm{V} / \mathrm{V})$. The preparation method was used as described by Mossoud et al. (2018).

\subsection{Cinnamon oil-nano particles preparation:}

Nano - emulsion of the plant oil was prepared according to Sjostrom and Bergenstahi (1992); Asnawi et al. (2008). The oil samples were diluted with a large amount of water after that an emulsifier material (Tween 20) was added at rate of $1 \mathrm{ml} / \mathrm{liter}$ combination of emulsifiers to prevent particle agglomeration. After that nano emulsion was subjected to $55 \mathrm{w}$ of ultra-sonic treatment for $2 \mathrm{~min}$ using a high-power ultra-Sonication probe then stored at $4^{\circ} \mathrm{c}$ until using to bioassays.

All nano - essential oils prepared on National Research Center (NRC) Cairo, Egypt.

\section{6- Toxicity tests:-}

\section{1- Silica nano particles: -}

One gram of nano silica was mixed with $100 \mathrm{~g}$ wheat to obtain $(1 \% \mathrm{w} / \mathrm{w})$. In the same way the concentrations were made by mixed $0.8,0.6,0.4$ and $0.2 \mathrm{~g}$ of nano silica with 100 -gram wheat as concentrations. Ten grams of wheat grains were used to each treatment. Thirty adult insects were introduced to each treatment and incubated at $28 \pm 1{ }^{\circ} \mathrm{C}$ and $65 \pm 5 \%$ R.H. Three replicates were used for each treatment. For control only talk powder was used for food treatment. Adult mortalities of $S$. oryzae were recorded after one and two weeks from the beginning of treatment.

\subsection{Nano plant oils used:}

The concentration $2 \%$ of nano cinnamon and mentha oils used as stock, which diluted with tween20 to obtain $1,0.5,0.25$ and $0.125 \%(\mathrm{v} / \mathrm{v})$ concentrations. Ten grams of wheat grains were used in each treatment. Thirty adult insects were introduced to each treatment and incubated at $28 \pm 1{ }^{\circ} \mathrm{C}$ and $65 \pm 5 \%$ R.H. Three replicates were used for each treatment. For control only tween-20 was used for food treatment. Mortalities were recorded one and two weeks after treatment. Mortality percentage was corrected by Abbott formula (1925) as following:

\section{Corrected morality $\%=$}

$\%$ mortality in treatment- $\%$ mortality in control

$\%$ mortality in control - 100

\section{7- Progeny test:}

The adults were removed from the treated jars after 14 days. The insect progeny was inspected after 60 days post-treatment and the reduction in the progeny was calculated according to the following equation.

Reduction \% =

$\frac{\text { No. of adults in control }- \text { No. of adults in treatment }}{\text { No. of adults in control }} \times 100$

\section{8- Germination test:-}

Germination tests were carried out according to the international rules for grain testing (Anonymous, 1966) to show the effect of treatment by different concentrations on grain germination. Germination was investigated at initial time and after the end of storage period (2 weeks).

\section{Statistical analysis:-}

The toxicity data were analyzed using Probit analysis to estimate the $\mathrm{LC}_{50}$ and $\mathrm{LT}_{50}$ (Ld. p line) (Finney, 1971), using computer program of Noack and Reichmuth (1978).

The statistical analysis was carried out using ANova with two factors under significance level of 0.05 for all results using SPSS. Data were treated as complete randomization design according to Steel $\boldsymbol{e t}$ al. (1997).

\section{Results and Discussion}

1- Efficacy of nano silica on mortality and reduction in the progeny of $S$. oryzae at 28 $\pm 1^{\circ} \mathrm{C}$ and $65 \pm \mathrm{RH}$.

The effect of nano silica on adult mortality and reduction in progeny of Sitophilus oryzae are presented in Table 1. The results showed that the mortality percentage was increased with increase of treatment time and concentrations at all treatments. Mortalities reached 100, 92.22, 86.67, 80.0 and $63.33 \%$ at concentrations of $1,0.8,0.6,0.4$ and $0.2 \%$ after two weeks, respectively. Reduction in progeny was between 100.0 - $64.66 \%$ at various tested concentrations of nano silica. The $\mathrm{LC}_{50}$ value of nano silica (Table 4) to adult of $S$. oryzae two weeks post treatment was $0.125 \%(\mathrm{~W} / \mathrm{W})$. Also, the time needed to obtain $50 \%$ mortality for adult were 1.68 day (Table 5). These data was in agreement with Padmasri et al (2018) who estimated the effect of nano silica, nano alumina and nano clay of different dosages 500,250 and 125 ppm on Sitophilus oryzae control. Nano silica at $500 \mathrm{ppm}$ showed the superior performance in mortality one day after treatment and also inhabited oviposition and no adult emergence of S.oryzae was observed. Also, Mesbah et al., (2017) found that the mortality of the adult increased by increasing the exposure time and concentration. In addition, no emerged adult insects were observed at the concentrations of 1.0 and $2.0 \mathrm{~g} \mathrm{~N} \mathrm{SPS} / 100 \mathrm{~g}$ broad bean seeds. On the other hand, Zayed (2018) studied two nano-particles, silica oxide $\left(\mathrm{Sio}_{2}\right)$ and aluminum oxide $\left(\mathrm{Al}_{2} \mathrm{O}_{3}\right)$ against S.oryzae adult. The results indicated that mortality (\%) increased and weight loss 
(\%) decreased with increase in concentration and exposure period. $\mathrm{Sio}_{2}$ had the most effect as compared with $\mathrm{Al}_{2} \mathrm{O}_{3}$ and also, significantly inhibited the number of progeny of S.oryzae adults.

\section{2- Efficacy of nano cinnamon oil on mortality and reduction in the progeny of S.oryzae at $28 \pm$ $1^{\circ} \mathrm{C}$ and $65 \pm 5 \%$ RH.}

The obtained results on the efficacy of cinnamon nano oil against S.oryzae are given In Table 2, adult mortality percentage of S.oryzae ranged from 55.52 to $33.32 \%$ after one week and increased to reach 91.11 and $50.0 \%$ after two weeks treatment of cinnamon nano oil. Also, reduction in progeny after 60 days ranged between 96.2 - $64.6 \%$ for all tested concentrations. $\mathrm{LC}_{50}$ value of the tested nano cinnamon oil, after two weeks of the treatment was $0.163 \%$ (Table 4). Also, the time needed to achieve $50 \%$ mortality was 2.09 day for adult (Table 5).

\section{3- Efficacy of nano Mentha oil on insect mortality and reduction in the progeny of S.oryzae at $28 \pm$ $1^{\circ} \mathrm{c}$ and $65 \pm 5 \%$ RH.}

Table 3 showed the highest percentages of $S$. oryzae adult mortality (90 and $76.7 \%$ ) post the treatment of wheat grains with nano mentha oil concentrations of 1 and $0.8 \%$ after two weeks, respectively. Reduction in progeny of emerged $S$. oryzae decreased with increasing concentration of nano mentha oil after 60 days especially with concentration of 1 and $0.8 \%$ which reached 95.5 and $96.7 \%$, respectively. Results in Table 4 revealed that the sub lethal concentrations ( $\mathrm{LC}_{50}$ value) of nano mentha oil, was $0.321 \%$ after 14 days of the treatment. Furthermore, the results obtained in Table 5 indicated that the time needed to kill $50 \%$ adult of S.oryzae was 2.32 day. These results are similar to those obtained by Sabbour and Abd El-Aziz (2016) who study the effect of essential oils (bulk and nano phase) of purslan, mustard and castor oil against larvae and adult of almond moth Ephestia cautella under laboratory and stored conditions. The tested oils caused high mortality percentages $(\%)$ and decreased the number of laid eggs with increasing concentrations.

Negaban et al. (2012) who studied the toxic effects of nano capsules of essential oil from Cumin cyminum against Tribolium castaneum. The fumigant toxicity from nano - capsules $\left(\mathrm{LC}_{50}=16.25 \mathrm{ppm}\right)$ were highly effective than pure essential oil $\left(\mathrm{LC}_{50}=32.12\right.$ ppm) with 7 days of exposure. Masumeh et al. (2017) investigated the insecticidal activity of Artemisia haussknechtii essential oil and encapsulated in nano particles against Tribolium castaneum and Sitophilus oryzae. It was demonstrated mortality of 100 percent of Sitophilus oryzae in the concentration of $166 \mathrm{ppm}$.

\section{Germination study:-}

Results in Table 6 indicated that no significant differences were found in germination of wheat grains treated with various nano oils comparison with control. These results were harmony with Mohammadjavad (2013) who found that silver nanoparticles and nano - silica has increased grain germination. Also, Pankaj et al., (2018) studied the effect of four nanoparticles $\left(\mathrm{Tio}_{2}, \mathrm{Zno}_{2}\right.$, nicked and chitosan) on wheat grain germination. grains soaked with nanoparticles especially $\mathrm{Tio}_{2}$, chitosan and $\mathrm{Zno}_{2}$ proved to enhance germination and seedling growth indices of wheat crop.

Table 1. Effect of nano silica particles on mortality and progeny against $S$. oryzae at $28 \pm 1{ }^{\circ} \mathrm{c}$ and $65 \pm 5 \% \mathrm{R} . \mathrm{H}$

\begin{tabular}{ccccc}
\hline $\begin{array}{c}\text { Concentration } \\
(\mathbf{w} / \mathbf{w}) \%\end{array}$ & \multicolumn{2}{c}{$\%$ Mortality } & $\begin{array}{c}\text { Mean No. of the progeny } \\
\text { after 60 days }\end{array}$ & $\begin{array}{c}\text { Reduction in } \\
\text { Progeny \% }\end{array}$ \\
\cline { 2 - 3 } $\mathbf{1}$ & $88.89 \pm 1.52$ & $100.0 \pm 0.0$ & 0.0 & 100.0 \\
$\mathbf{0 . 8}$ & $72.65 \pm 2.31$ & $92.22 \pm 2.31$ & 5.65 & 90.46 \\
$\mathbf{0 . 6}$ & $70.56 \pm 1.53$ & $86.67 \pm 2.50$ & 10.0 & 83.15 \\
$\mathbf{0 . 4}$ & $66.65 \pm 2.31$ & $80.0 \pm 1.15$ & 16.66 & 71.19 \\
$\mathbf{0 . 2}$ & $43.32 \pm 1.15$ & $63.33 \pm 2.31$ & 21.0 & 64.60 \\
control & $0.0 \pm 0.0$ & $0.0 \pm 0.0$ & 204.0 & \\
\hline
\end{tabular}

Table 2. Effect of nano cinnamon oil on mortality and progeny against $S$. oryzae at $28 \pm 1^{\circ} \mathrm{c}$ and $65 \pm 5 \%$ R.H.

\begin{tabular}{lcccc}
\hline $\begin{array}{l}\text { Concentration } \\
(\mathbf{w} / \mathbf{w}) \%\end{array}$ & \multicolumn{2}{c}{ \% Mortality } & $\begin{array}{c}\text { Mean No. of the progeny } \\
\text { after 60 days }\end{array}$ & $\begin{array}{c}\text { Reduction in } \\
\text { Progeny \% }\end{array}$ \\
\cline { 2 - 3 } $\mathbf{2}$ & $55.52 \pm 2.65$ & $91.11 \pm 1.15$ & 7.0 & 96.2 \\
$\mathbf{1}$ & $63.32 \pm 2.50$ & $81.11 \pm 1.50$ & 10.0 & 95.0 \\
$\mathbf{0 . 5}$ & $58.88 \pm 1.53$ & $75.56 \pm 2.65$ & 15.0 & 92.6 \\
$\mathbf{0 . 2 5}$ & $44.44 \pm 2.50$ & $62.22 \pm 1.53$ & 44.0 & 78.4 \\
$\mathbf{0 . 1 2 5}$ & $33.32 \pm 2.30$ & $50.0 \pm 1.15$ & 56.4 & 64.6 \\
control & $0.0 \pm 0.0$ & $0.0 \pm 0.0$ & 204.0 & \\
\hline
\end{tabular}


Table 3. Effect of nano mentha oil on mortality and progeny against $S$. oryzae at $28 \pm 1^{\circ} \mathrm{c}$ and $65 \pm 5 \% \mathrm{R} . \mathrm{H}$

\begin{tabular}{lcccc}
\hline \multirow{2}{*}{$\begin{array}{c}\text { Concentration } \\
\text { (w/w)\% }\end{array}$} & \multicolumn{2}{c}{ \% Mortality } & $\begin{array}{c}\text { Mean No. of the progeny } \\
\text { after 60 days }\end{array}$ & $\begin{array}{c}\text { Reduction in } \\
\text { Progeny \% }\end{array}$ \\
\hline 2 & $35.6 \pm 1.15$ & $90.6 \pm 0.58$ & 7.5 & 95.5 \\
1 & $28.7 \pm 1.53$ & $76.7 \pm 1.04$ & 15.3 & 90.7 \\
0.5 & $21.8 \pm 2.31$ & $65.6 \pm 2.51$ & 33.1 & 84.6 \\
0.25 & $16.7 \pm 1.53$ & $53.9 \pm 2.31$ & 48.5 & 74.3 \\
0.125 & $8.87 \pm 2.31$ & $44.5 \pm 1.53$ & 70.0 & 61.0 \\
control & $0.0 \pm 0.0$ & $0.0 \pm 0.0$ & 271 & \\
\hline
\end{tabular}

Table 4. Toxicity of different tested materials on S. oryzae at two weeks.

\begin{tabular}{lcccc}
\hline Tested materials & LC50 \% & LC90 \% & Slope \pm SD & R \\
\hline Nano-silica & 0.125 & 0.522 & $1: 806 \pm 0.554$ & 0.791 \\
\multirow{2}{*}{ Nano cinnamon oil } & $(0.072-0-219)$ & $(0.298-0.914)$ & & \\
\multirow{2}{*}{ Nano mentha oil } & 0.163 & 0.778 & $1.929 \pm 0.518$ & 0.884 \\
& $(0.099-0.267$ & $(0.474-1.278)$ & & \multirow{2}{*}{0.815} \\
\hline
\end{tabular}

Table 5. Lethal time value and parameters of probit regress line estimated for the adult stage of S.oryzae

\begin{tabular}{lcccc}
\hline Tested materials & LT & LTays & Slope \pm SD & R \\
\hline Nano-silica & 1.68 & 3.81 & $3.62 \pm 1.54$ & 0.888 \\
\multirow{2}{*}{ Nano cinnamon oil } & $(1-45-1.96)$ & $(3.17-4.58)$ & & 0.925 \\
\multirow{2}{*}{ Nano mentha oil } & 2.09 & 4.94 & $3.42 \pm 1.33$ & \multirow{2}{*}{0.917} \\
\hline
\end{tabular}

$\mathrm{R}=$ Correlation coefficient of regression line

$\mathrm{SD}=$ Standard deviation of the mortality regression line.

Table 6. Effect of nano silica, cinnamon and mentha oils on germination

\begin{tabular}{lcc}
\hline Tested materials & Conc. $(\mathbf{g} . / \mathrm{kg})$ & Germination percentage \% \\
\hline & 1 & $100.0 \pm 0.0$ \\
Nano silica & 0.8 & $99.0 \pm 1.52$ \\
& 0.6 & $100.0 \pm 0.0$ \\
& 0.4 & $99.0 \pm 1.00$ \\
Nano cinnamon oil & 0.2 & $100.0 \pm 0.0$ \\
& 2 & $88 \pm 0.37$ \\
& 1 & $88 \pm 0.56$ \\
& 0.5 & $92 \pm 0.60$ \\
Nano mentha oil & 0.25 & $92 \pm 1.08$ \\
& 0.125 & $95 \pm 1.00$ \\
& 2 & $86 \pm 1.90$ \\
& 1 & $88 \pm 1.94$ \\
Control & 0.5 & $91 \pm 1.70$ \\
& 0.25 & $90 \pm 1.00$ \\
& 0.125 & $92 \pm 2.32$ \\
\hline
\end{tabular}

\section{References}

Asnawi, S.; Abd Aziz, A. and Rand khains, A. (2008): Formulation of geranium, oil loaded solid lipid nano particles for mosquito repellent application. Journal of Chemical and Natural Resources Engineering, 2: 90 - 99.

Abbott, W.W. (1925): A method of computing the effectiveness of an insecticide. J.Econ. Entomol. 18, (2): $265-267$.
Anonymous, N. (1966): International rules for seed testing proceeding of international seed testing. Association, 64:1304 - 1305.

Baloch, U. K. (1992). Integrated pest management in food grains. Food and Agriculture organization of the United Nations and Pakistan Agricultural Research council, Islamabad, Pakistan, 117pp.

Finney, D.J. (1971): Probit Analysis. Cambridge University Press, Cambridge, London, 333pp. 
Lee, S.; Peterson, C.J. and coats, J.R. (2003): Fumigation toxicity of monoterpenoids to several stored product insects. Journal of Stored Products Research. 39: 77 - 85.

Sabbour, Magda, M. and Abd El-Aziz, shadia, E. (2016): Roll of these essential oils and their nano against Ephestia cautella (lepidoptera - Pyralidae) under laboratory and store conditions. International Journal of Pharm Tech. Res., 9 (10): $194-200$.

Maryam, N.; Moharrumipour, S.; Zandi, M.; Hashemi, S.A. and Ziayee, F. (2012): nanoinsecticidal activity of essential oil from cuminum cyminum on Tribolium castaneum. Arber Professional Congress Services, Turkey pp: 63-68.

Masumeh, K.; pakravan, P.; Azandryani, A. H.M; Negahban, M. and Ghamari, E. (2017): Fumigant toxicity of Artemisia haussknechtii essential oil and its nano encapsulated against Tribolium castaneum and Sitophilus oryzae under laboratory conditions. Journal of Entomology and Zoology Studies, 5(2): 1776 - 1783.

Mesbah, H. A.; Tayeb, E.H.M.; A. M. A. Kordy and Ghitheeth, Haider.H. (2017): Comparative insecticidal activity of nano and coarse silica on the chinese beetle callosobruchus chinensis (L) (Coleoptera: Bruchidae).Alexandria Science Exchange Journal. 38 (4): 654 - 660.

Mohammadjavad seghatoleslami (2013): Silver nano particles and magnetic field effects on seed and essential oil yield of carum copticum under water stress condition. Journal of Herbs, Spices \& Medicinal plants. 19: $357-364$.

Mossoud, M.A.; Adel, M.M.; zaghloul o.A.; Mohamed M.I.E. and Abdel-Rheim, K.H. (2018): Eco-friendly nano-emulsion formulation of Mentha piperita against stored product pest Sitophilus oryzae. Adv. Crop. Sci. Tech.pp133.

Noack, S. and Reichmuth, C.H. (1978): Einrechnerisches verfahren zur bestimmung von beliebigen dosis-werten eines wirkstoffes aus empirisch dosis- wirkungs - daten Mitt. Boil Bundesanstalt fur Land Forst Wirtsch, Berlin Dahlem, Haft, 185: 1- 49.
Owolade, O.F and Ogunleti D.o. (2008): Effects of titanium dioxide on the diseases, development and yield of edible cowpea. Journal of Plant Protection Research, 48 (3): 329 - 336.

Padmasri, A.; Aruna kumara, J.; Anil, B.; Rameash, k.; Srinivas C.; Vijaya Lakshmi, K. and Pradeep, T. (2018): Efficacy of nanoparticles against rice weevil [Sitophilus oryzae (Linnaeus)] on maize seeds. Journal of Entomology and Zoology Studies, 6(5): 326 - 330.

Pankaj, S.R.; Rajeewkumar, P.R and Priyan, K. (2018): Effect of nano particles on wheat seed germination and seeding growth. International Journal of Agricultural and Bio Systems Engineering, 12(1): $13-16$.

Park, I.k.; Lee, S.G.; Choib D.H.; Park, J.D. and Ahnay, J. (2003): Insecticidal activities of constituents identified in the essential oil from leaves of Chamaecyparis obtusa against Callosobruchus chinesis (L) and Sitophilus oryzae (L.). J. Stored Prod. Res., 39: 375 - 384.

Shaaya, E.; Ravid, U.; Paster, N.; Juven, B., Zisman, U. and Pissarev, V. (1991): Fumigant toxicity of essential oils against four major stored product insects. Journal of Chemical Ecology, 17: 499-504.

Sjostrom, B. and Bergenstahl, B. (1992): Preparation of submicron drug particle in lecithin - stabilized O/W emulsion. I. Model studies of the precipitation of cholesterylacetate. Int. J. Pharm., 88: 53.62.

Steel, R.G.D.; Torrie, J.H. and Dickey, D. (1997): Principle and procedure of statistics. A biometrical Approach $3^{\text {rd }}$ Ed. McGraw Hill Book Co. Inc., New York, pp. 352 - 358.

White sides, G.M. and Gryzbowski, B. (2002): Self - assembly at all scales science (Washington D.C.), 295: $2418-2421$.

Zayed, G. M.M (2018): Nano - particles: A recent approach for controlling stored grain insect pests. Academia Journal of Agricultural Research, 6(5): $088-094$. 


\section{سميه مستحضر النانومترى للزيوت المختلفة على الحشرات الكاملة لسوسة الارز تحت الظروف المعملية

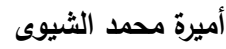 \\ قسم وقاية النبات - كلية الزراعة بمشتهر - جامعة بنها}

تم معاملة الحشرات الكاملة لسوسة الارز بجزيئات السيلكا وزيت القرفة والنعناع فى صورة النانو . أوضحت الننائج أن جزيئات السيكا

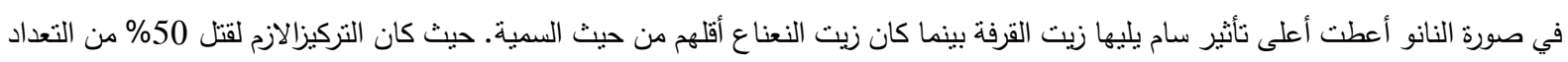
لجزيئات السليكا النانومترية 1250.1 \% وكان الوقت اللازم لقتل 50\% من التعداد 1.68 يوم للحشرات الكاملة لسوسة الارز يليها زيت القرفة

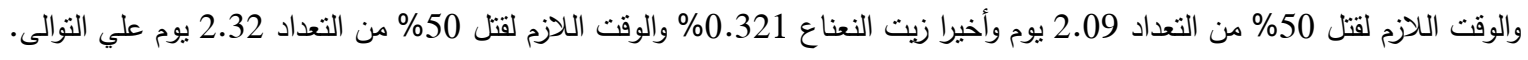

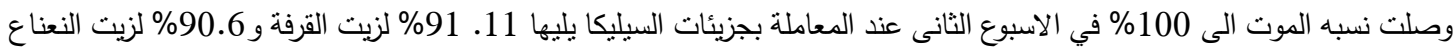

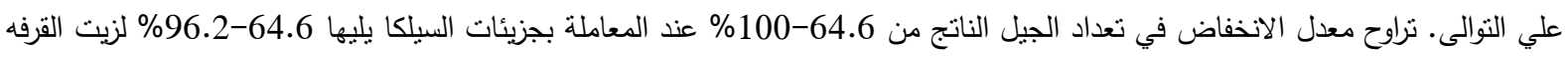

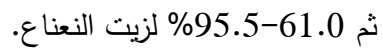

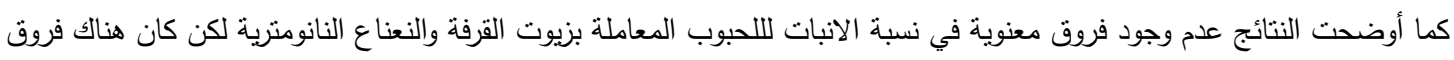
واضحة في حالة الحبوب المعاملة بجزيئات السيلكا النانومترية. وعامة تحتاج مستحضرات النانو للمزيد من الدراسات لمعرفة ددى أمانها وتأثيرها على البيئة عند استخدامها لمكافحة الحشرات. 